\title{
IMPERATIVES IN CONTACT. LINGUISTIC INTERACTIONS ON THE SAKHALIN ISLAND*
}

Keywords: Sakhalin linguistic diversity, language contact, grammatical accommodation, imperative

\begin{abstract}
The main goal of this paper is to describe some functional and formal similarities in the expression of imperatives and hortatives in various languages which are spoken in the Sakhalin Island. The suggestion is made that such similarities might have been contact-induced language changes that resulted from two common mechanisms: structural (inflectional) borrowing and grammatical accommodation.
\end{abstract}

da quod iubes et iube quod vis Augustine of Hippo, Confessiones 10.29.40

\section{Introduction}

In this paper, we tackle the issue of language contact in the Sakhalin Island. The main goal of this work is to call attention to some commonalities in the domain of the imperative-hortative system and put forward an explanation whereby such similarities are better seen as the result of contact-induced processes.

The Sakhalin Island is the home to various ethnic groups (minorities). Among the earliest settlements we can count those of the Ghilyak (a.k.a Nivkh, see Janhunen 2016: $4 \mathrm{fn} \mathrm{1),} \mathrm{Ainu} \mathrm{and} \mathrm{Uilta} \mathrm{(or} \mathrm{Orok).} \mathrm{Uilta} \mathrm{is} \mathrm{a} \mathrm{member} \mathrm{of} \mathrm{the} \mathrm{Southern} \mathrm{branch} \mathrm{of}$

* This paper was written thanks to a Juan de la Cierva postdoctoral Fellowship from Spain's Ministerio de Ciencia e Innovación (Ref. IJCI-2014-19343). 
the Tungusic family, whereas Ghilyak and Ainu are language isolates. The Ewenki (Northern Tungusic) and the Russians (Slavic, Indo-European) are latecomers to the Sakhalin Island (see, i.a., Forsyth 1992: 48-69, and esp. 201-228).

All of them, with the sole exception of Russian (the dominant language) and Ainu, which vanished at the end of the $20^{\text {th }}$ century, are endangered languages. Typologically speaking, Tungusic is a typical representative of the agglutinative type, whereas Ghilyak and Ainu are (moderately) polysynthetic.

\section{Imperatives on Sakhalin}

The expression of imperatives and commands in Ghilyak and Tungusic involves fairly elaborated paradigms with a set of endings whose origins are disputed. In stark contrast to Ghilyak and Tungusic, Ainu employs a series of particles (adverbial elements) which cannot be described as belonging into a paradigm. ${ }^{1}$

In the next section I describe the imperative subsystem of each language. Basic diachronic information will be provided.

\subsection{Sakhalin Ewenki and Uilta (Orok)}

In the Tungusic tradition, a tacit distinction is made between the First (= Present) and the Second (= Future, sometimes subdivided into "Immediate Future" and "Distant Future") Imperatives. "First Imperatives" refer to orders, requests and wishes, addressed to a second person. "Second Imperatives" mainly express future actions or general events, addressed to a first or third person (various labels are used, like "optatives, benefactives, hortatives", depending on the situation). In the following, only the so-called "First Imperative" will be discussed. Table 1 shows the Sakhalin Ewenki (Bulatova 1999: 28) and Negidal (Myl'nikova, Cincius 1931: 164; Cincius 1982: 35; Xasanova 1986: 74) paradigms (“ $\sim$ ” stands between free-variants) and a synoptic overview of the Uilta endings as well as the endings assumed for the parent language as reconstructed in Alonso de la Fuente (2012: 31). ${ }^{2}$ Table 2

In the Northeast Eurasian context, the imperative category has already been the subject of some studies on language contact. Pakendorf (2007: 208-241) suggests that the Future Imperative of Yakut may have been modeled after the Future Imperative of Ewenki by the well known mechanism of contact-induced grammaticalization (see, i.a., Heine, Kuteva 2005: 13-21). This is an interesting alternative explanation for the traditionally held view that the Future Imperative of Yakut is of Mongolic origin.

2 The standard version of the history of the Tungusic imperative can be found in Xasanova (1986: 54-75). Xasanova dealt with both First and Second Imperatives, whereas Alonso de la Fuente (2012) only with First Imperative forms. Although Xasanova's and Alonso de la Fuente's analyses agree on some points, there are many points of disagreement. One issue of special importance involves purely methodological considerations regarding reconstruction. Xasanova interprets all irregularities in terms of phonetic developments or ad hoc segmentations, whereas Alonso de la Fuente opts for a more holistic view where both analogical formation and paradigm leveling play a crucial role. 
shows in more detail the distribution (allomorphy) of the First Imperative endings in Uilta according to verb classes (note that, unless otherwise stated, 〈ä〉 in all Tungusic forms stands for $/ \partial /$ ).

\begin{tabular}{|c|c|c|c|c|}
\hline & $\begin{array}{c}\text { Sakhalin } \\
\text { Ewenki }\end{array}$ & Negidal $^{3}$ & Uilta & $\begin{array}{l}\text { Common } \\
\text { Tungusic }\end{array}$ \\
\hline $\mathbf{1}$ & $-k t a$ & $-k t a /-x t a$ & - & $*_{-}$g $\breve{1}=$ ta \\
\hline 2 & $-k a l$ & $-k a l /-x a l$ & $-w /-(r) u$ & $\varnothing \sim{ }^{*}$-ru \\
\hline 3 & - gin & -gin, -yin & - & ${ }^{*}$-gi.ni \\
\hline 1 EXCL & $-k p u n$ & -yiwun & - & *-gi.wari (?) \\
\hline INCL & -gaar $\sim$-gaat & -yan -gay, -yay & & \\
\hline 2 & $-k a l l u$ & -kasun /-xan -xasun & $-((r) u-) s u$ & $\varnothing \sim{ }^{*}$-su \\
\hline 3 & $-k t \ddot{n}$ & -gitin, -yitin & - & ${ }^{*}$-gi.ti(n) \\
\hline
\end{tabular}

Table 1. First Imperative paradigm in various Tungusic languages

\begin{tabular}{|c|c|c|c|c|c|}
\hline \multirow{2}{*}{ Class } & \multirow{2}{*}{ I } & \multirow{2}{*}{ II } & \multirow{2}{*}{ III } & \multicolumn{2}{|c|}{ IV } \\
\hline & & & & $\mathbf{A}$ & B \\
\hline 2SG & 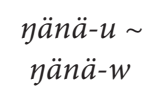 & buu-ru & $u n-u$ & olonu-ru & $\begin{array}{c}b i-u \sim b u \sim \\
b i-w\end{array}$ \\
\hline 2PL & yänä-u-su & buu-ru-su & $u n-u-s u$ & olon-u-su $u^{4}$ & $b i-u-s u$ \\
\hline base & $\begin{array}{l}\text { yänä- } \\
\text { 'to go' }\end{array}$ & $\begin{array}{l}\text { buu- } \\
\text { 'to give' }\end{array}$ & $\begin{array}{c}\text { un- } \\
\text { 'to say' }\end{array}$ & $\begin{array}{c}\text { olono- } \\
\text { 'to be scared' }\end{array}$ & $\begin{array}{c}b i- \\
\text { 'to be' }\end{array}$ \\
\hline
\end{tabular}

Table 2. Uilta First Imperative paradigms (Petrova 1967: 107, 109; Ozolinja 2013: 320-324)

3 Endings from the Upper Amgun and Lower Amgun dialects are separated by "/". Upper Amgun is beyond the influence of its Northern Tungusic relatives, as a consequence of what there is no trace of the 1PL.EXCL ending (in agreement with Southern Tungusic, where there is no pronominal exclusivity). Curiously enough, only Xasanova is explicit regarding the inclusive vs. exclusive distinction. She does not mention -yan. The $\eta$-allomorph of the 3SG, 1PL and 3PL endings, which in theory is restricted to nasal bases (Myl'nikova, Cincius 1931: 182), seems to have generalized to all bases in Lower Amgun. To this day remains unexplained Xasanova's dual ending -naay (Xasanova 1986: 74; Gusev 2015: 66). Since we lack a good synchronic description of this unexpected form, I will refrain from making any historical inference.

4 Note that singular and plural stems are identical. In analogy to what happens in the rest of verb classes, the resulting plural base olonu- (from olon- $u$-su $<{ }^{*}$ olono-u-su $<{ }^{*}$ olono-ru-su) replaced the regular singular form ${ }^{*}$ olono-ru $\rightarrow$ olonu-ru. 
The history of the First Imperative is very complicated. In a first moment, the parent language used the formant ${ }^{*}$-gi- (in origin, an optative marker or a desiderative particle) exclusively with first and third persons: $1 \mathrm{SG}^{*}$-gi=ta $>^{*}$-kta, $35 \mathrm{SG}^{*}$-gi.ni $>^{*}$-gin or $3 \mathrm{PL}^{*}$-gi.tin $>^{*}$-ktin, where $=t A$ is an emphatic particle and ${ }^{*}$.ni and ${ }^{*}$.tin belong to the set of personal possessive markers. Northern Tungusic languages extended the model to the second person and first exclusive plural person via analogical formations, e.g. 1PL.EX -kpun (Sakhalin Ewenki) and -yiwun (Negidal) < Proto-Northern Tungusic ${ }^{*}$-gi.pun (but Literary Ewenki -kta-pun is the analogical extension of 1SG $-k t a),{ }^{3}$ with - $p u$ - being taken, again, from the set of personal possessive markers, etc.

As for Uilta and some other languages (Kili, Kilen, Literary Nanay), they seem to have preserved the original endings for the second person, which did not involve the formant ${ }^{*}$-gi-. From a synchronic standpoint, Uilta does not retain any trace of ${ }^{*}$-gi-. However, it has been suggested that Uilta -ru may be related to Manchu $-r a o$, the interrogative form of the imperfective participle (used to express polite requests), which according to some specialists is the continuation of the analytic construction *-ra.gi oo 'please, you (do something)' (see, e.g., Benzing 1956: 138, who reconstructs ${ }^{*}$-ra.ki oo) and includes the formant ${ }^{*}$-gi.

The allomorphy of the $2 \mathrm{SG}$ ending in Uilta is caused by the regular sound change ${ }^{*}$-r- $>\varnothing$ (which do not apply before long vowels) and ${ }^{*}$-nr- $>{ }^{*}$-nn- $>-n$ - (this development concerns only third class verbs, i.e., nasal base verbs). The ending - $r u$ analogically extended to denominal verbs in -na-, $-\eta a-,-m a$ - and $-s u$ - that now belong to subtype A of the fourth class verbs (subtype B includes traditional irregular verbs like $b i$ - 'to be').

Unlike Sakhalin Ewenki, Uilta has the ending - $y a$ which is used to express a command politely or affectionately, e.g. yänä-yä 'please go!' (Ikegami 2001/1959: 27, 29).

Pevnov (2009: 120-121) mentions some irregular forms in the 3SG and 3PL, e.g. 3SG sinjääl(l)o! 'let him come!', käärräälo! 'let him catch fish with a seine (sweepnet)!', and 3PL sinjääl(l)ol 'let them come!'. 'These forms contain the present participle marker -raa and the mysterious ending $-l(l) o$ (note that Pevnov comments that E.A. Bibikova, the informant, preferred variants with a single /l/).

\subsection{Ghilyak}

The imperative paradigm in Ghilyak distinguishes person and number. Dialectal differences are pertinent: Amur Ghilyak has the special ending - $k t a \sim-x t a$ for 1SG, which has no counterpart in Sakhalin Ghilyak. Table 3 shows the imperative paradigm in both AG and SG (for more on their use, see Gruzdeva 1992: 56-63, 1998: $46-47,2001)$ :

The component $-k t a \sim-x t a$ of the 1 SG ending -nïkta $\sim-n \ddot{x} x t a$ is of Tungusic origin. Variant $-k t a$ faithfully retains the original, Tungusic phonetic make-up,

3 In some Northern Tungusic languages (Ewenki, Ewen, Solon), the first person plural distinguishes between exclusive and inclusive. This is a secondary phenomenon which is usually explained as the result of Mongolic influence (Bolon Nanay, a Southern Tungusic variety, is said to have it because of contacts with Northern Tungusic).

4 In the original, 〈sind'éél(l)o!’, «keerréélo〉, «sind'éél(l)ol», respectively. 


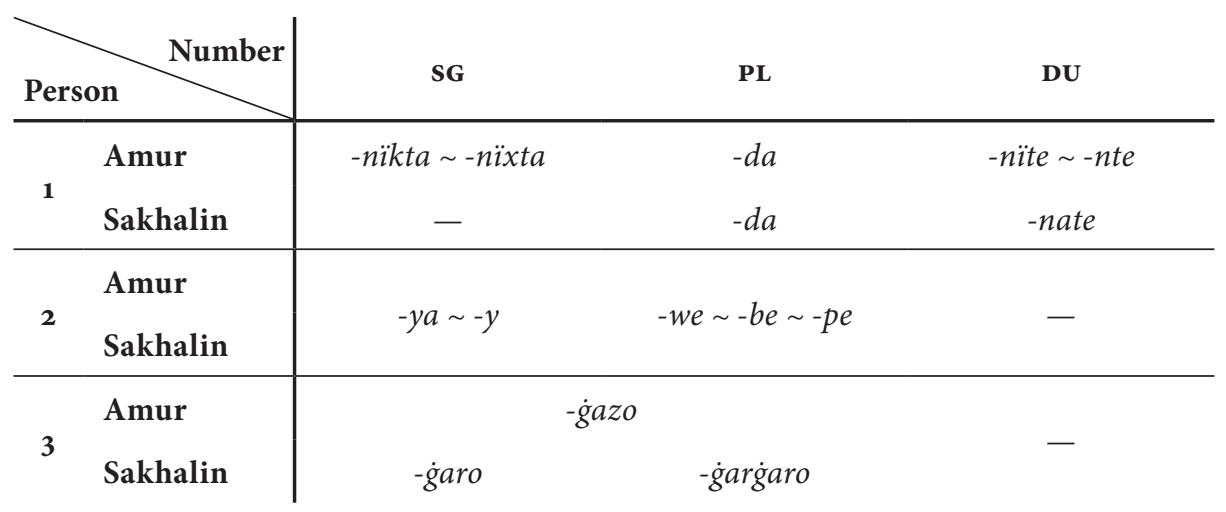

Table 3. Nivkh imperative markers (after Gruzdeva 1998: 34, «ì stands for [i], 〈gं〉 for [b])

while $-x t a$ is the regular outcome in Negidal, where ${ }^{\star} \mathrm{k}$ yields / $\mathrm{x} /$ between vowels and before voiceless consonants (see, i.a., Benzing 1956: 28-29). The first part -nï- is commonly explained as the future participle (see, i.a., Panfilov 1965: 132). As we will see, it is a common trait that futures and imperatives are usually connected on a solid semantic basis.

It is worth noting that future -nï- only appears in the Amur dialect, whereas in Sakhalin Ghilyak the corresponding future tense marker is - $i$ - (Panfilov 1965: 92-93). The vowel correspondence AG /i// SG /a/ which can be observed in 1DU -nïte (AG) vs. -nate (SG) is regular. It reflects a certainly not very archaic pattern of the parent language, i.e., the raising of /a/ to /i/ due to the presence of /e/ in the next syllable, though the regular condition involves /i/, as in SG wat vs. AG vic, from * wa-tti 'iron' or SG daf vs. AG $d y f$, from *dVbi 'house' (this issue has been already discussed by Austerlitz 1982: 84, 1984: 4, 1994: 231). As for the variant -nte, it results from the syncopated $\dagger$-nïte. ${ }^{5}$ All this seems to point out that the original future tense marker was ${ }^{*}$-na-, and in SG it has been preserved as a relic only in the 1DU ending of the imperative (the question why ${ }^{*}$-na- was replaced by - $i$ - should not concern us here).

Allomorphy in $2 \mathrm{PL}$ is purely phonological: $\mathrm{V}^{\mathrm{o}}-w e, \mathrm{C}$ [voiced] ${ }^{\circ}-b e$ and $\mathrm{C}[$ voiceless $]^{\circ}$-pe. The be-variant may occur to with vowel bases, e.g. wi-we or wi-be 'you go!'. Interestingly enough, Ghilyak $-y(a)$ can be attached, for emphatic purposes (Panfilov 1965: 131), to 2PL forms: $-w e-y$, etc., and even to the 2SG $-y a$, i.e., ${ }^{*}-y a-y>$ $-y e-y$ and $1 \mathrm{PL}-d a>^{*}-\mathrm{da}-\mathrm{y}>-d e-y$ (with $a>e$ due to vowel assimilation or, perhaps, analogy with the $2 \mathrm{PL}$ forms). The best conclusion we can draw from this property of $-y(a)$ is that the original system had an opposition 2sG $\varnothing$ vs. 2 PL $-P e$, which was enlarged with $-y a$ at a later stage. The gap in the 2 SG was fulfilled with a new ending, and afterwards the attachment of $-y a$ to the 2 PL form become optional (contextually restricted).

The special polite formation -na-we (SG) is used when addressing an elder or unfamiliar person. Gruzdeva (1998: 34) suggests that -na-may correspond to the 2PL

5 Ghilyak stress, although not constant, usually falls on the first syllable of non-monosyllabic words. However, it is fixed on the vocative and (the last syllable of) imperative suffixes. 
iterative marker -na-. It seems more natural, however, to assume that it is a paradigmatic extension of the use of the future participle in the 1SG and 1DU endings.

Interestingly enough, Dobrushina and Goussev (2005: 191) claimed that "[...] the inclusive-exclusive distinction cannot be absent in the imperative but present elsewhere". In case there is no corresponding inclusive-exclusive distinction encoded in the 1PL imperative markers, the authors propose that this function may be carried by the dual. This is what happens in Ghilyak: 1PL imperative - $d a=$ augmented inclusive, whereas $1 \mathrm{DU}$ imperative $-n(i) t e=$ minimal inclusive.

\begin{tabular}{|c|c|c|}
\hline & Pronouns & Imperative \\
\hline (Sakhalin) Ewenki & $\begin{array}{l}\text { EXCL mit } \\
\text { INCL buu }\end{array}$ & $\begin{array}{l}\text { EXCL -kpun } \\
\text { INCL -gaar } \sim \text {-gaat } \\
\text { (First Imperative) }\end{array}$ \\
\hline Ghilyak & 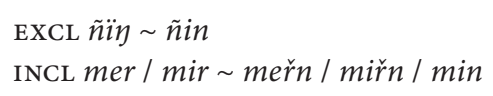 & $\begin{array}{l}\mathrm{PL}(\mathrm{EXCL})-d a \\
\mathrm{DU}(\mathrm{INCL})-n(i) t e\end{array}$ \\
\hline Uilta & 1PL $b u$ & $\begin{array}{l}\text {-ya-pta } \\
\text { (Second Imperative) }\end{array}$ \\
\hline $\begin{array}{ll} & \text { Sakhalin } \\
\text { Ainu } & \\
& \text { Hokkaidō }\end{array}$ & $\begin{array}{l}\text { 1PL anoka } \\
\text { EXCL ciokay } \\
\text { INCL } a(n) o k a y\end{array}$ & LOG.1PL.INCL. $=r o(o)$ \\
\hline
\end{tabular}

Table 4. Correlation of personal pronouns and imperative endings in 1PL forms

\subsection{Ainu}

There is no imperative paradigm in Ainu. The expression of imperatives and commands is carried out by various particles and adverbial elements. They all have in common that always occur in final position (hence the Japanese label shüjoshi 終助詞 or final particles). General descriptions of Ainu (see, i.a., Chiri 1942/1973: 569-570; Tamura 1988/200o: 174, 241, 244, 247; Dettmer 1989: 831-858; Satō 2008: 126-129) mention numerous imperative constructions. We will focus on three of them: (1) =yan, which is the regular imperative marker, $(2)=r o$, which is the regular hortative marker, and (3) the analytic constructions, of rather marginal use, $k u n i-p=n e$ or $-p(e)=n e=n a$, which contain the nominalizer element $-p(e)$ 'thing' (allomorphic distribution: $\mathrm{C}^{\circ}-p e$ and $\mathrm{V}^{\mathrm{o}}-p$ ). (1) is described as the regular imperative $2 \mathrm{PL}$ and polite marker (the imperative 2SG marker is expressed by the bare base of the verb, e.g. nu '(thou) listen!'), (2) corresponds to the hortative and (3) to the polite imperative in special contexts used when gods speak to humans, or adults speak to children, e.g.

(1) $n u=y a n$ !

listen $=\mathrm{IMPT} .2 \mathrm{PL}$

'listen up!' (said to two or more people, or said to a higher ranked person) 
(2a) paye-an=ro

go.PL-(LOG.)1PL.INCL=HOR

'let's go'

(2b) $k$-arpa $=$ ro ? e-arpa yakka pirka

1SG.S-GO.SG=HOR 2SG.S-go.sG if good

'Should I go? It's OK if you come.'

(3a) a-macíhi e-ne kuni- $p=n e$ ruwe $=n e=n a$

INDF.A(LOG)-wife.POSS 2.SG.S-COP FUT $=$ NMLZ $=$ COP EVD $=\mathrm{COP}=\mathrm{EMPH}$

'you will be my wife'

(3b) aynu hunara $e-k i=p=n e=n a$

man search 2SG.S-do $=\mathrm{NMLZ}=\mathrm{COP}=\mathrm{EMPH}$

'go search for someone!'

For examples like (2a), where LOG.1PL.INCL verb form is followed by the particle ro, Bugaeva (2004: 94) prefers the label cohortative.

The distribution of these structures within Ainu deserves some comment. There is plenty of examples for (1) and (2) in both Hokkaidō Ainu (HA) and Sakhalin Ainu (SA). As expected, (2) surfaces as =roo in SA. In East Coast SA, Piłsudski (1912: 81 note 19) says that yan is "[...] the characteristic ending of the 2nd person pl. of the imperative." Examples include (note that Piłsudski 1912 = Majewicz 1998: 1-272):

(4) Péntaći ámba ojaśi emuś ani an-ćíute, anókane jaxka táta rajan, emúsihi anećíu karáte ànkosuratáte, hóxpa paj-án; śimma eći pájki-ćiki vónneka-ján.

'When (I) thrust with the sword at Birch-bark-Torch, I also (was as) dead there, when (I) thrust (and) let go (my) sword (from my hand), (I) left it (and) came (away); tomorrow when you rise (go and) see.'

(Piłsudski 1912: 77, lines 16-19)

(5) Náx án-kusu tánto śine tó né-kusu ćiśe oxta jáj tóri-janua!

'Therefore today, for one day only, remain at home without working (outside).' (Piłsudski 1912: 119-120, lines 57-58)

The last example contains the sequence yan=wa which is made of the imperative marker yan and the sentence final particle wa (Piłsudski 1912: 130, note 58 believes that $w a$ is also an imperative marker).

As for (2), Piłsudski’s texts also contain examples of $=$ roo, but there is no description of it (in p. 108 note 8 we are told that ipiśanaxćiro "[...] 'let us ask them; 1 pers[son]. plur[al]. imp[erative]. of the verb piśi 'to ask, to enquire”"):

(6) Téta japán-ćiki ipiśanaxćiró. Tani kotan koro utara ćéx é kotan ónne pajéxći rúhe an; oháćirùmpe horóxći án-kusu, ćiśe orovano pa numa a rúhe an.

'The steersman said: "Let us land and enquire. It is evident (that) the people of the village have now gone to (their) fishing place; there is a person who is left, because smoke rises from the house."

(Piłsudski 1912: 99, lines 8-10) 
The hortative use of $=$ roo is well known in West Coast SA:

(7) kee, tani ipe-an=roo

INTJ now eat-1PL-HOR

'come on, let's eat now!' (Murasaki 1976: 88, 201)

The history of the particles which are involved in the expression of imperatives and commands in Ainu is not entirely clear (see Table 5 below).

\begin{tabular}{|c|c|c|c|}
\hline Proto-Ainu & $\begin{array}{l}\text { *ya-n (sG) } \sim^{*} \text { ya-p (PL) } \\
\text { 'to go (towards the shore), to land' }\end{array}$ & $?$ & ${ }^{*}$-p $(e),{ }^{*}$ ne \\
\hline Common Ainu & * =ya.n & *=ró & ${ }^{*}$-p $(e)=$ né... \\
\hline Sakhalin Ainu & $=y a n$ & $=r o o$ & $-h V=n e(e) \ldots$ \\
\hline Hokkaidō Ainu & $=y a n$ & $=r o$ & $-p(e)=n e=n a$ \\
\hline
\end{tabular}

Table 5. Evolution of Ainu imperative expressions (grammaticalizations)

yan comes from $y a-n$ 'to go (towards the shore); to land'. Although this verb is only used with singular referents (the corresponding plural form is ya- $p$, cf. $y a$ 'land, shore', see Hattori 1981/1964: 212), the final segment - an in yan may have been associated semantically with 1PL marker -an, which is used as respectful second person (curiously enough, Batchelor 1905: 520a claims that yan as imperative is used sometimes with singular referents). The grammaticalization of verbs of movement into hortative markers (or, more generally, directives, i.e., markers involved in the expression of orders, suggestions or exhortations) is very common (see, i.a., Heine, Kuteva 2005: 69-70 'to come', 159-160 'to go' and, more recently, Mauri, Sansò 2014: 171-177, where the authors show that the 'go' > simple [non-motion] directive path does not entail the previous or simultaneous grammaticalization of 'go' into prospective or future markers).

The origin of the sentence final particle $=r o(o)$ is unknown. This particle is used "[...] to seek approval from another for an action one is thinking of doing" (Tamura 1988/200o: 174), therefore sentences like paye-an=ro 'let's go' are understood prototypically as 'shall we go?'. SA has a variant $=r o h$, with final $-h$ which could go back to any stop. There is, however, no lexical items which could have evolved into a hortative marker via grammaticalization (perhaps rok 'to sit', only with plural referents, although verbs such as 'to sit' and the like are involved in the grammaticalization of morphemes which express habitual or continuous action). It is more than likely that $\mathrm{SA}=$ roh goes back to ${ }^{*}=$ ró $-k$, where $-k$ is the same (mysterious) formant attached to other connective (postpositional) and adverbial elements, e.g. SA naa 'still' nah 'in this way', SA hetah=taa 'come on, quickly' (HA hetak EMPH), SA pah=no 'till, up-to; until' (HA pakno id.), HA yak yakka 'if' (perhaps related to the interrogative-assertive particle $=y a$ ), etc. 
The construction $=p e=n e=n a$ contains the well known nominalizer $-p(e)$, the copula $n e$, and the sentence final particle (also called "suggestive particle") na (SA naa) which appears in various other imperative constructions for emphatic purposes. This construction has not self evident counterpart in Sakhalin Ainu, and to find one may require some elaboration. Since $-p(e)=n e=n a$ appears already in Epic $(=$ Old $)$ Ainu, there is good ground to assume that it is very archaic, put another way, it may have been present in the common ancestor of Hokkaidō Ainu and Sakhalin Ainu.

In HA, the nominalizer -pe has two allomorphs: $\mathrm{C}^{\circ}-p e$ and $\mathrm{V}^{\mathrm{o}}-p$. In SA only the $\mathrm{C}^{\circ}$-pe variant has survived. The $\mathrm{V}^{\mathrm{o}}$-variant would regularly yield $-h$, as is the case with all stops in final position in SA, e.g. Common Ainu * sine 'one' $\Rightarrow{ }^{*}$ sine-p 'one thing' > HA sinep \& SA sineh, but CA ${ }^{\star}$ wan 'ten' $\Rightarrow{ }^{\star}$ wan-pe 'ten things' $>$ HA \& SA wanpe. There are numerous clausal structures which contain the formant $-h V$, where $\mathrm{V}$ is the echo-vowel which replicates the vowel quality of the immediately preceding syllable. This element could be actually identified with the original $\mathrm{V}^{\mathrm{o}}-\mathrm{p}$ variant of the nominalizer -pe in constructions like, e.g., kuyee-he sunke 'what I said is a lie', lit. 'the thing I said is a lie' or eramu-hu neeno kii wa 'please, do as you like', lit. 'please, do the thing you like' (Murasaki 1978: 32 s.v. -hV'-ing'), which in pre-SA would look like ${ }^{\star} k u-y e ́-p$ sun-ke and *eramu-p né=no kí wa.

Note that in some cases SA $-h V$ corresponds to the affiliative marker (- $h V$ in HA) which in SA has been extended to verb formations in modal, evidential, or aspectual sentences, and to clausal nominalizations (this is one very salient feature of SA in opposition to HA). While in some cases such a nominalization via possessive marker is reasonable (if not just correct, see Bugaeva 2016), my suggestion here is based on the fact that the formal as well as functional similarities between $\mathrm{HA}=p e=n e .$. and SA $-h V=n e e . .$. might be not coincidental. As for echo-vowel, it arose in ${ }^{\star} V^{\circ}-h \rightarrow-h V$ by analogy to the possessive marker which is used in similar syntactical contexts.

It is possible to speculate that the common ancestor of SA and HA had an expressive construction ${ }^{*}-\mathrm{p}(\mathrm{e})=$ ne, of unknown meaning or function, which evolved differently in HA (polite imperative with suggestive na) and SA (e.g. in - $h V=n e$ 'an kusu 'how surprising is...; isn't?', etc.).

\section{Common origin or chance similarity?}

From the description above, four formal and functional similarities can be spotted after a cursory inspection. ${ }^{6}$ In the following sections we will analyze these similarities

6 Moellendorf (1894: 142) proposed to relate the segment -te in Ghilyak 1DU *-nate (> AG -n(i)te, SG -nate) with the same segment in the Uilta 1SG and 1PL Future Imperative, e.g. Class I:

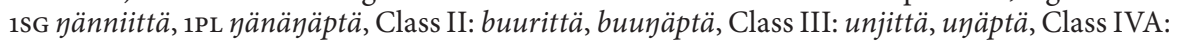
olonositta, olononopto, Class IVB: bittä, biyäptä (due to analogy with plural forms, there

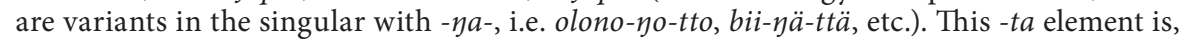
presumably, the same as in Sakhalin Ewenki 1SG -kta $<{ }^{*}$-gï-ta, etc. Although tempting, this comparison will not be commented upon here. It is problematic on two accounts: (1) phonetically, there is no apparent reason why Ghilyak speakers would have to choose the Uilta 
and try to establish whether they are borrowings (grammatical replication) or, on the other hand, they are the result of chance similarity.

\section{1. (Sakhalin) Ewenki -kta vs. Amur Ghilyak -nï-kta -nï-xta}

The common origin of these endings is obvious (Gusev 2015: 64-66). Sound correspondences and functional load do not pose any problem. The direction of the borrowing must be Tungusic (Negidal) $\rightarrow$ Ghilyak, since the Tungusic ending has a likely etymology (imperative formant ${ }^{*}$-gi- plus emphatic particle ${ }^{*}=$ ta). The fact that this ending only surfaced in AG, and not in SG, is purely anecdotic. The adoption of the future participle -ni- for the 1SG ending may be the result of analogical pressures from the dual ending -nï-te.

\subsection{Uilta -ya vs. Pan-Ghilyak -y(a) vs. Pan-Ainu =yan}

Like the previous comparison, this one is also self-evident (see recently Pevnov 2016: 58-59) and requires less elaboration. Since there is a likely etymology for Pan-Ainu =yan, and it is simpler to assume a route "from Hokkaido to Sakhalin" than the other way around, the direction of the borrowing should be Ainu $\rightarrow$ Ghilyak $\rightarrow$ Uilta. Segment $-n$ in yan could have been interpreted by Ghilyak speakers as a plural marker (Gruzdeva 1998: 56) and, it being deemed unnecessary, dropped. As for Uilta speakers, they may have felt that final $-n$ has something to do with noun class $-n$, and drop it too, or perhaps they hear it mainly from Ghilyak speakers, where $-n$ was already absent.

Austerlitz (1958) proposed to see in Pan-Ghilyak - $y(a)$ a complex suffix made of the proper imperative ending $-y$ (with an allophone $-i$ before consonants) and the vocative $-a$. There is nothing wrong with this etymology, as is well founded on internal facts. However, it does not take into account Ainu or Uilta data, and then fails to provide a more global explanation.

\subsection{Sakhalin Ainu $=$ roo vs. Uilta -10}

The irregular imperative (hortative) forms sinjääl(l)o! 'let him come!', sinjääl(l)ol 'let them come', or käärräälo 'let him catch fish with a seine (sweep-net)!', which have been mentioned above, contain the complex endings SG -rää-l(l)o, PL -rä̈̈-l(l)o-l, where 3PL -llol contains the regular plural marker -l (Ikegami 2001/1959: 34-35). The history of these endings has some resemblance to that of the Uilta optative (or Second Imperative, see Petrova 1967: 109-111; Ozolinja 2013: 324-328) endings 3SG - yatta vs. 3PL - yattal (Ikegami 2001/1959: 38; Kazama 2008: 110-111). There is little doubt that the singular form - yatta is made of the future marker - ya and

harmonic variant -tä (interpreted as /te/ in Ghilyak), and (2) functionally, we have no readily explanation for the lack of agreement in person: the Ghilyak ending is only used with 1DU referents, whereas the Uilta ending refers to both singular and plural persons (the category of dual is absent in Tungusic). 
the desiderative particle $=t a$. The original plural formation is $-\eta a-l=t a$, where $\mathrm{PL}$ $-l$ follows the ending $-y a$ and stands before the particle $=t a$ (the variant $-y a l t a$ has been recorded by Ikegami 2001/1959: 37-38). When the original consonant cluster - $l t$ - assimilated to - $t t$-, number distinction was blurred. PL - $l$ was attached once again, this time in total final position (as the identities of ending and particle faded away after the change -lt- >-tt-), yielding -yattal. It is legitimate to assume that the original singular form was ${ }^{* *}$-nata, which regularly becomes - yatta (gemination of intervocalic consonants is regular in Uilta). At that point, SG and PL had identical forms, hence the attachment of the plural marker $-l$ to the plural forms.

The same explanation may hold true for the complex endings SG -rää-l(l)o, PL -rää$l(l)_{o-l}$, that is, gemination may have caused firstly the impossibility to distinguish SG from PL, and then the attachment of the plural ending - $l$. Once the plural ending $-l$ has been added, gemination becomes a redundant feature. This could explain informants' hesitation regarding the presence or absence of gemination.

As for the ultimate origin of the formant ${ }^{*}$-lo, formal and functional similarities with the Sakhalin Ainu hortative $=$ roo are undeniable. ${ }^{7}$ This Ainu element, once taken by Uilta speakers, could have been attached to the present participle in -raa, as with the emphatic element *-gi in the analytic construction *-ra.gï oo mentioned above. Rhotic dissimilation is a regular process in Uilta, hence we have ${ }^{\star}$-rää-ro > -rää-lo (shortening of long vowels in final position is not uncommon).

Influence from the regular future tense markers SG - $l a$, PL $-l a-l$ cannot be denied out of hand, for the path of the future tense and the imperative mood crosses very often from the historical and typological viewpoints (see, i.a., Aikhenvald 2010: 363 ).

Less likely, the use of the the Ghilyak interrogative particle $=l a \sim=l(o)$ (Nedjalkov, Otaina 2013: 116, 124) with first person plural referents could have derived into an hortative interpretation, and then been transferred to Uilta. However, such a use has not been documented in Ghilyak and therefore should remain in the realm of speculation.

In this particular case, maybe we are dealing with grammatical accommodation $^{8}$ rather than with inflectional borrowing. In all the involved languages, similar linguistic material $-r V /-l V$ with various original functions (future tense marker, interrogative particle, assertive particle, etc.) met in the middle when the Ainu hortative diffused across the island.

7 It is tempting to include here SG - $\dot{g} a r o$, but not AG - $\dot{g} a z o$. Rhotacism seems the most natural solution for the sound correspondence AG - $z$ - vs. SG - $r$-, which is similar to the one in the instrumental AG $-s$ vs. SG $-r$, put another way, AG preserves the oldest state of affairs (i.e., Proto-Ghilyak ${ }^{*}$-gazo, instrumental ${ }^{*}$-s, etc.), whereas SG has innovated. Therefore, the safest solution to the question regarding the similarities between $\mathrm{SA}=$ roo and the -ro part in SG - garo is to admit that in this case we are dealing with chance similarity.

8 Aikhenvald (2001: 180) defines grammatical accommodation as the "[...] syntactic deployment of a native morpheme on the model of a phonetically similar morpheme in the diffusing language' (that is, the language which is the source of diffusion)". As an example of this phenomenon, she argues that Tariana - $y a$, originally an emphatic particle, has now an imperative value after some Tucano languages, where $-y a$ is the regular marker of imperative. 


\subsection{Pan-Ghilyak -we vs. Common Ainu *-p(e)=ne...}

Pan-Ghilyak 2SG -we is reminiscent of the Ainu element -pe in the HA analytic constructions $-k u n i-p=n e$ or $-p(e)=n e=n a$. Form and function seem compatible. Since the history of the Ainu constructions is more or less clear, and the components which make up these constructions have unambiguous etymologies, the direction of the borrowing has to be Ainu $\rightarrow$ Ghilyak. This raises some interesting questions: (1) Ghilyak borrowed the Ainu formant - $p(e)$ before spirantization had taken place in SA, (2) once - $p(e)$ was introduced in the Ghilyak system, it was modified to adapt to Ghilyak phonotactics, i.e. $\mathrm{C}^{\mathrm{o}}$-pe $\rightarrow \mathrm{V}^{\mathrm{o}}$-we, (3) in Ainu, the -pe element does not imply an imperative meaning by itself, Ghilyak speakers had to isolate -pe from the Ainu analytic construction and attribute to it the value and function of an imperative ending. Points (1) and (2) do not seem insurmountable obstacles to admit the validity of this comparison. Point (3), however, would seem to favour the interpretation that chance similarity is the most reasonable explanation.

\section{Discussion}

Although the idea that the Sakhalin Island could be characterized as a linguistic area is not very popular yet (Yamada 2010: 70-71), perhaps due to the scarcity of materials or the lack of studies specifically dealing with language contact. This notwithstanding, languages in close contact situation tend to converge structurally and avoid changes towards divergence, and the linguistic configuration in the Sakhalin Island complies with this well-known rule. ${ }^{9}$

The four cases discussed in the previous section involve the transfer of inflectional material and particles. It has been clear from Weinreich's (1953: 31-33) classical handbook on language contact that derivational affixes are more easily transferable from one language to another than inflectional affixes. In a classical formulation, Thomason and Kaufman (1988: 74-75) situated derivational borrowing at level 3 of their borrowing scale, whereas inflectional borrowing occupied level 4 , that is, the highest level. However, recent literature insists that, although clearly disliked, inflectional borrowing is far more common than it is generally assumed (see, i.a., Thomason 2014).

It is only natural that in the exceptional cases of inflectional borrowing, it is assumed that both the source and the recipient languages must be involved in situations characterized by intense contact and, frequently but not exclusively, by close genealogical relatedness. Tungusic, Ainu and Ghilyak have very similar typological profiles, what in theory makes easier that typical language contact processes like borrowing or grammatical accommodation take place.

For the exception that confirms it, see Campbell and Grondona's study (2010). They describe the linguistic situation in Misión La Paz, where multilingualism (dual-lingualism and linguistic endogamy) has not lead to structural convergence or, so far, there is no evidence of change towards similar convergence. 
Although we have not mentioned it at length, the role of dominant languages in the region, i.e., Russian and Japanese, had, needless to say, an enormous impact on the indigenous languages. There are traces of such an influence in the imperative, too.

In a rather simplistic, impressionistic fashion, we can say that given the differences in typological profiles, Russian influence simplified or reduced the original agglutinative nature of the Tungusic languages, whereas contacts with other typologically closer languages, e.g. Yakut (Sakha, a Turkic language) or Buriat and Dagur (Mongolic languages), triggered the reuse of internal resources (adaptation) or the copy of new paradigms (for the particular case of Yakut-Tungusic contacts, see Pakendorf 2007, 2014; Johanson 2014).

Since Russian influence is the most pervasive, changes over time can be easily documented and observed. The most conspicuous effects of language shift (language attrition) in the case of Tungusic-Russian contacts are: change in the basic constituent order (from a very strict AOv to a much more freer one or just Avo under certain circumstances), substantial reduction of derivational morphology, and introduction of "typological anomalies", e.g. prepositions instead of postpositions, clause-combining strategies with only finite verbs (including or not connectors) instead of the well-known sequences of converb or nominalization plus single finite verb form (Grenoble 2013: 359).

The influence of Russian can also be observed in the imperative (see Gruzdeva 2000 for a detailed account, and Gruzdeva 2015: 168-173 for a brief overview taking into account Russian influence on Ghilyak in general). Gruzdeva (2000: 127) suggests that the 3PL ending - $\dot{g}$ argaro, only registered in the Sakhalin Ghilyak dialect, may have arisen as the result of influence from the corresponding construction in Russian where a finite verbal form in the 3PL is used. As Gruzdeva notes, in Ghilyak reduplication conveys the grammatical function of plurality, even though this mechanism is practically out of use.

As for Japanese, it has been remarked not once that some imperative structures have been transferred to Ainu (this is more obvious in the dialects used on the island of Hokkaidō), e.g. $n u=w a$ en-kore $=y a n$ listen $=\mathrm{CON} 1 \mathrm{SG} . \mathrm{O}-\mathrm{give}=\mathrm{IMPT}\}$ 'please listen to me!', where Ainu kore replicates Japanese ...てください -te kudasai (from くれる kureru 'to give, receive' = Ainu kore 'to give') with Ainu yan providing the polite/high register nuance of the Japanese expression (see, i.a., Refsing 1986: 283 fn. 60).

The suggestion has been made in this paper that identical episodes occurred, but in this case with the exclusive participation of the indigenous languages. Historical contact among the different groups is well studied and the context for linguistic interaction is beyond any doubt (see, i.a., Gruzdeva 1996; Janhunen 2013: 34-35, 44; Wurm 1996; Wurm, Mühlhäusler, Tryon 1996, vol. 1, map 108; Yamada 2010). From the $13^{\text {th }}$ or early $14^{\text {th }}$ centuries until the $17^{\text {th }}$ century, Uilta, Ghilyak and Ainu shared spatial coordinates: the Ainu inhabited the southern part of the island, whereas the Uilta and the Ghilyak, although later relocated to northern quarters (most of the Uilta migrated to Hokkaidō), back then also lived in central areas. In Gruzdeva's own words: 


\begin{abstract}
At the turn of the 2oth century, the language situation in the area was characterized by an active multilingualism caused by various socio-cultural reasons (joint residing, common forms of economic activities, mixed marriages, etc.). However, Nivkh has had little effect on neighbouring languages. It is often contended that the aboriginal neighbours of the Nivkhs easily acquired a knowledge of all the other local languages in use, except Nivkh. That is why, the Nivkhs had to express themselves in Ainu, Orok, etc., not in the own language, in their relations with the neighbours. A general rule which characterized the contacts between the aboriginal population and the immigrants, was communication in the languages of the latters. Though the original population was dominated by stronger nationalities, due to their isolated life as hunters and fishermen, they could keep their native languages and culture for a long time. (Gruzdeva 1998: 8; see also Gruzdeva 2000: 122).
\end{abstract}

Such an active interaction resulting in the borrowing of various imperative strategies (be that endings or structures) is not unusual. Similar settings, sometimes far more exuberant, have been described in the literature. Aikhenvald (2010: 370-394) provides a good number of such scenarios, the most remarkable being perhaps the multilingual framework in the Vaupés River Basin in north-west Amazonia, a region that extends from Brazil to Colombia and encompasses half-a-dozen East Tucanoan languages and one Arawak language, i.e., Tariana (further details in Aikhenvald 1999, 2007b). Here, too, numerous endings and structures associated with imperatives and commands have been transferred from one language to another (Aikhenvald 2007a: 129-131, 2008).

Why imperatives? Aikhenvald (2010: 390-392) argues that frequency and pragmatic patterns conspire in order to fulfill the "[...] desire to be able to say what one's neighbor can say-making 'the categories existing in the languages that are in contact mutually compatible and more readily intertranslatable", and "[i]n a situation of intensive language contact, similar situations are conceptualized in similar ways and warrant similar verbal description. [...] This brings us to a tendency to achieve word-for-word and morpheme-for-morpheme intertranslatability, enhanced by the existence of a perceivable 'gap' which facilitates diffusion." The expressive nature of imperative and command utterances facilitates the identification of salient elements (discourse markers) that favours their isolation, identification and further diffusion among different languages.

\title{
5. Conclusions
}

Table 8 summarizes the four etymological connections analyzed in the third section (plus Gruzdeva's identification of SG 3PL - $\dot{\text { gargaro }}$ as a structural borrowing from Russian). Note that formants likely related are separated by discontinuous lines, whereas dubious connections are marked with double-crooked lines. Solid-double lines divide genealogical groups. There is nothing surprising in that Ghilyak seems to be the only language involved in all the suggested links. Due to the difficulty of their language, the Ghilyak had to learn others' languages. This explains why 
Ghilyak usually is the receiving language, and rarely the donor language (no one was learning Ghilyak).

Leaving aside the speculative nature of some of these comparisons, it should be clear by now that the Sakhalin Island has been the scenario of language contact situations the outcome of which, although not as spectacular as those observed in the case of other language leagues of the Sprachbund kind, could still prove useful to specialists interested not only in the history of the linguistic configuration in Sakhalin, but also in language contact in general.

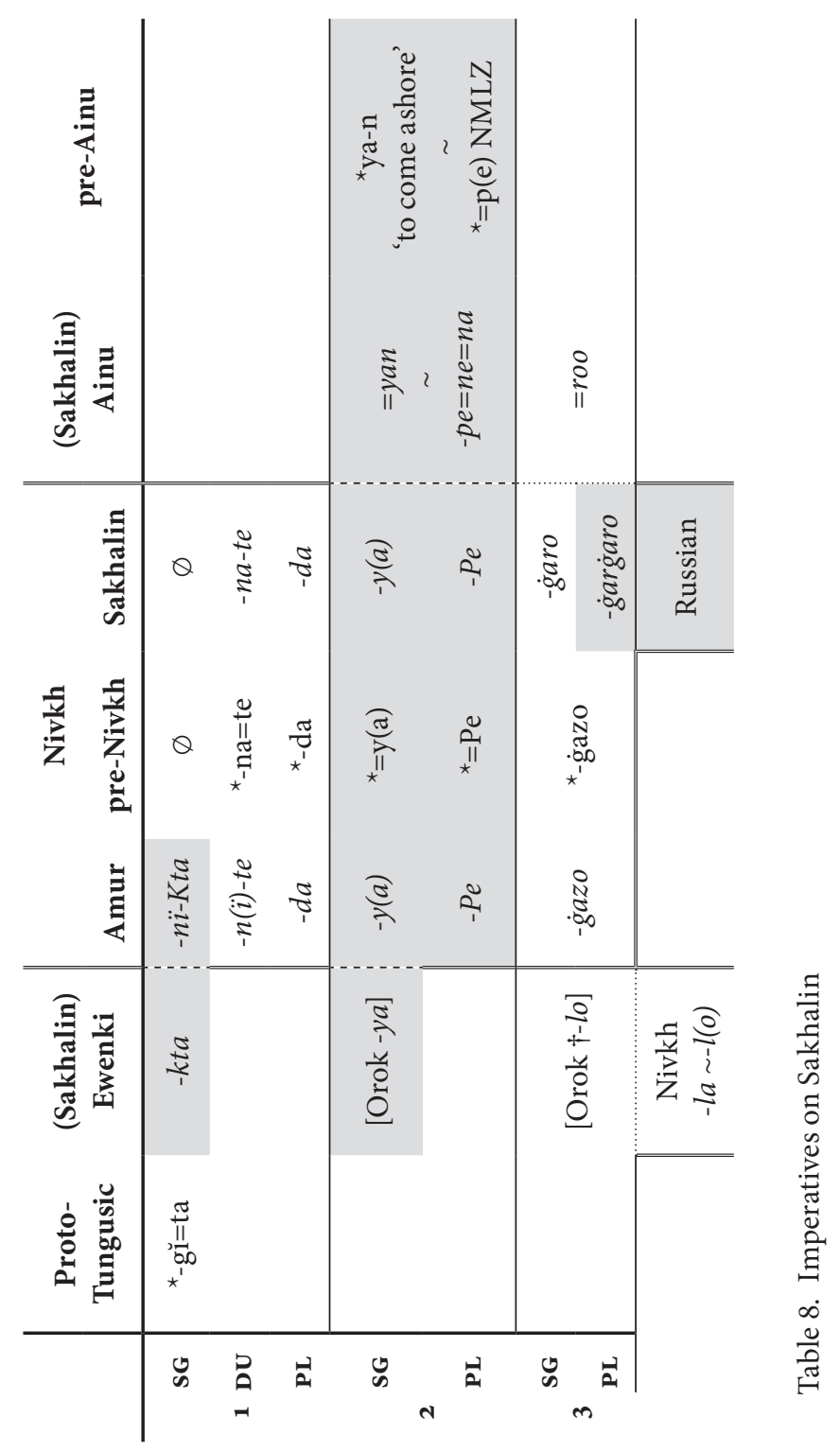




\section{Abbreviations}
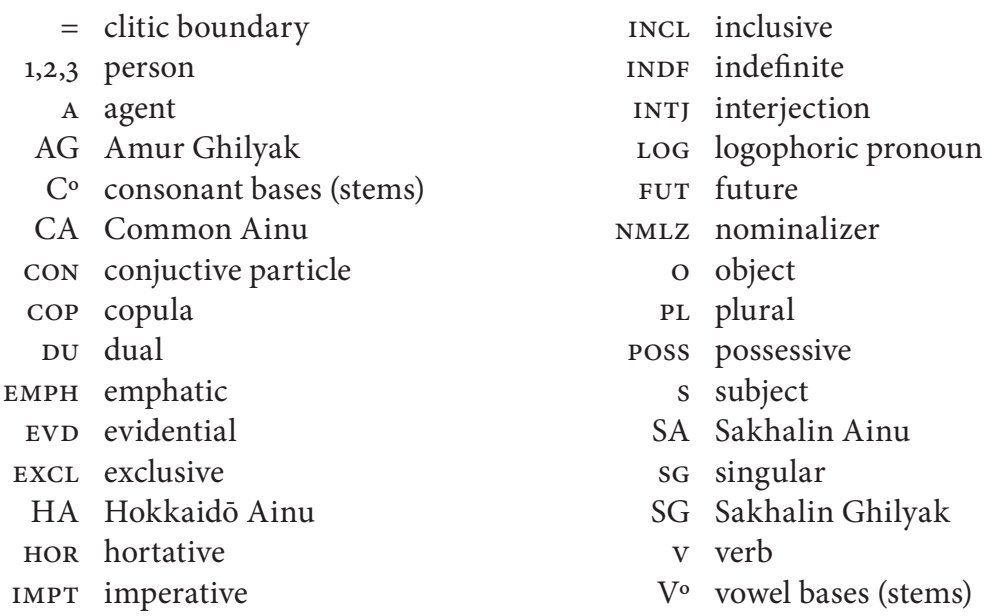

\section{References}

Aikhenvald A.Y. 1999. Areal diffusion and language contact in the Içana-Vaupés basin, north-west Amazonia. - Aikhenvald A.Y., Dixon R.M.W. (eds.). The Amazonian languages. Cambridge: 385-412.

Aikhenvald A.Y. 2001. Areal diffusion, genetic inheritance, and problems of subgrouping: A North Arawak case study. - Aikhenvald A.Y., Dixon R.M.W. (eds.). Areal diffusion and genetic inheritance. Problems in comparative linguistics. Oxford: 167-194.

Aikhenvald A.Y. 2007a. Language contact in Amazonia. Oxford.

Aikhenvald A.Y. 2007b. Semantics and pragmatics of grammatical relations in the Vaupés linguistic areas. - Aikhenvald A.Y., Dixon R.M.W. (eds.). Grammars in contact: A crosslinguistic typology. Oxford: 237-266.

Aikhenvald A.Y. 2008. Multilingual imperatives: The elaboration of a category in Northwest Amazonia. - International Journal of American Linguistics 74.2: 189-225.

Aikhenvald A.Y. 2010. Imperatives and commands. Oxford.

Alonso de la Fuente J.A. 2012. The first imperative of Tungusic. - Studia Linguistica Universitatis Iagellonicae Cracoviensis 129: 7-34.

Austerlitz R. 1958. Vocatif et impératif en ghiliak. - Orbis 7.2: 477-481.

Austerlitz R. 1982. Gilyak internal reconstruction, 1: Seven etyma. - Folia Slavica 5.1-3: 81-88.

Austerlitz R. 1984. Gilyak internal reconstruction, 2: Iron and questions related to metallurgy. - Aronson H., Durden B. (eds.). Papers from the third conference on the non-Slavic languages of the USSR. Columbus $(\mathrm{OH}): 38-48$.

Austerlitz R. 1994. Gilyak internal reconstruction, 3: Ligneous matter. - Aronson H. (ed.). Non-Slavic languages of the USSR. Papers from the fourth conference. Columbus $(\mathrm{OH})$ : 229-233.

Batchelor J. 1905. An Ainu-English-Japanese dictionary. [2 ${ }^{\text {nd }}$ edition]. Tokyo.

Benzing J. 1956. Die tungusischen Sprachen. Versuch einer vergleichenden Grammatik. Wiesbaden.

Bugaeva A. 2004. Grammar and folklore texts of the Chitose dialect of Ainu (idiolect of Ito Oda). Suita. 
Bugaeva A. 2016. On the innovative nature of Sakhalin Ainu: Focusing on nominalization. Gruzdeva E., Janhunen J. (eds.). Crosslinguistics and linguistic crossing in Northeast Asia: Papers on the languages of Sakhalin and adjacent regions. Helsinki: 95-117.

Bulatova N.J. 1999. Jazyk saxalinskix èvenkov. Sankt-Peterburg.

Campbell L., Grondona V. 2010. Who speaks what to whom? Multilingualism and language choice in Misión La Paz. - Language in Society 39.1: 1-30.

Chiri Mashiho 知里真志保. 1942/1973. Ainu-gohō kenkyū. - Chiri Mashiho chosaku-shū. [vol. 3]. Tōkyō: 455-585.

Cincius V.I. 1982. Negidal'skij jazyk. Issledovanija i materialy. Leningrad.

Dettmer H.A. 1989. Ainu-Grammatik. [Teil 1: Texte und Hinweise B]. Wiesbaden.

Dobrushina N., Goussev V. 2005. Inclusive imperative. - Filimonova E. (ed.). Clusivity. Typology and case studies of inclusive-exclusive distinction. Amsterdam, Philadelphia: 179-211.

Forsyth J. 1992. A history of the peoples of Siberia. Russia's North Asian colony 1581-1990. Cambridge.

Grenoble L. 2013. The syntax and pragmatics of Tungusic revisited. - Bickel B., Grenoble L., Peterson D., Timberlake A. (eds.). Language typology and historical contingency. Amsterdam, Philadelphia: 357-382.

Gruzdeva E. 1992. Povelitel'nye predloženija v nivxskom jazyke. - Xrakovskij V.S. (ed.). Tipologija imperativnyx konstrukcij. Sankt-Peterburg: 55-63.

Gruzdeva E. 1996. The linguistic situation on Sakhalin Island. - Wurm S., Mühlhäusler P., Tryon D. (eds.). Atlas of languages of intercultural communication in the Pacific, Asia, and the Americas. [vol. 2.2]. Berlin, New York: 1007-1012.

Gruzdeva E. 1998. Nivkh. München.

Gruzdeva E. 2000. Aspects of Russian-Nivkh grammatical interference: The Nivkh imperative. - Gilbers D.G., Nerbonne J., Schaeken J. (eds.). Languages in contact. Amsterdam, Atlanta: 121-134.

Gruzdeva E. 2001. Imperative sentences in Nivkh. - Xrakovskij V.S. (ed.). Typology of imperative constructions. München: 59-77.

Gruzdeva E. 2015. Sociolinguistic and linguistic outcomes of Nivkh-Russian language contact. - Stolz C. (ed.). Languages empires in comparative perspective. Berlin: 153-181.

Gusev V. 2015. Some parallels in grammar between Nivkh and Tungusic languages. - Hoppō jinbun kenkyū 8: 63-75.

Hattori Shirō 服部四朗 (ed.). 1981/1964. Ainu-go hōgen jiten. Tōkyō.

Heine B., Kuteva T. 2005. Language contact and grammatical change. Cambridge.

Ikegami Jirō 池上二郎. 2001/1959. The verb inflection of Orok. - Ikegami Jirō (ed.). Tsungūsugo kenkyū. Tōkyō: 24-72.

Janhunen J. 2013. The Tungusic languages: A history of contacts. - Kim J., Ko D. (eds.). Current trends in Altaic linguistics. A Festschrift for Professor Emeritus Seong Baeg-in on his 80th birthday. Seoul: $18-60$.

Janhunen J. 2016. Reconstructio externa linguae Ghiliacorum. - Gruzdeva E., Janhunen J. (eds.). Crosslinguistics and Linguistic Crossings in Northeast Asia. Helsinki: 3-27.

Johanson L. 2014. A Yakut copy of a Tungusic viewpoint aspect paradigm. - Robbeets M., Bisang W. (eds.). Paradigm change: In the Transeurasian languages and beyond. Amsterdam, Philadelphia: 235-242.

Kazama S. 2008. The diachronic development of the Group III of Tungusic languages. Kurebito T. (ed.). Linguistic typology of the North. Tokyo: 103-123.

Majewicz A.F. (ed.). 1998. The collected works of Bronisław Pitsudski. [vol. 2: Materials for the study of the Ainu language and folklore (1912)]. Berlin, New York. 
Mauri C., Sansò A. 2014. Go and come as sources of directive constructions. - Devos M., van der Wal J. (eds.). COME and GO off the Beaten Grammaticalization Path. Berlin: 165-184.

Moellendorf P.G. von. 1894. The Ghilyak language. - The China Review 21: 141-146.

Murasaki Kyōko 村崎恭子. 1976. Karafuto ainu-go. Tōkyō.

Murasaki Kyōko 村崎恭子. 1978. Sakhalin Ainu. Tokyo.

Myl'nikova K.M., Cincius V.I. 1931. Materialy po issledovaniju negidal'skogo jazyka. - Tunguskij sbornik 1: 107-218.

Nedjalkov V.P., Otaina G.A. 2013. A syntax of the Nivkh language. The Amur dialect. Amsterdam, Philadelphia.

Ozolinja L.V. 2013. Grammatika orokskogo jazyka. Novosibirsk.

Pakendorf B. 2007. Contact in the prehistory of the Sakha (Yakuts): Linguistic and genetic perspectives. Utrecht.

Pakendorf B. 2014. Paradigm copying in Tungusic The Lamunkhin dialect of Ėven and beyond. - Robbeets M., Bisang W. (eds.). Paradigm change. In the Transeurasian languages and beyond. Amsterdam, Philadelphia: 287-310.

Panfilov V.Z. 1965. Grammatika nivxskogo jazyka. [part 2: Glagol, narečie, obraznye slova, meždometija, služebnye slova]. Moskva, Leningrad.

Petrova T.I. 1967. Jazyk orokov (ul'ta). Leningrad.

Pevnov A.M. 2009. On some features of Nivkh and Uilta (in connection with prospects of Russian-Japanese collaboration). - Tsumagari Toshirō (ed.). Saharin gengo sekai. Sapporo: $113-125$.

Pevnov A.M. 2016. On the Specific Features of Orok as Comparaed with the Other Tungusic Languages. - Gruzdeva E., Janhunen J. (eds.). Crosslinguistics and Linguistic Crossings in Northeast Asia. Helsinki: 47-63.

Piłsudski B. 1912. Materials for the study of the Ainu language and folklore. Cracow.

Refsing K. 1986. The Ainu language. Morphology and syntax of the Shizunai dialect. Aarhus.

Satō Tomomi 佐藤知已. 2008. Ainu-go bunpō no kiso. Tōkyō.

Tamura S. 1988/2000. The Ainu language. Tokyo.

Thomason S.G. 2014. When is the diffusion of inflectional morphology not dispreferred? Gardani F., Arkadiev P., Amiridze N. (eds.). Borrowed morphology. Berlin: 27-46.

Thomason S.G., Kaufman T. 1988. Language contact, creolization, and genetic linguistics. Berkeley.

Weinreich U. 1953. Languages in contact. Findings and problems. New York.

Wurm S. 1996. Indigenous lingue franche and bilingualism in Siberia (beginning of the 20th century). - Wurm S., Mühlhäusler P., Tryon D. (eds.). Atlas of languages of intercultural communication in the Pacific, Asia, and the Americas. [vol. 2.2]. Berlin, New York: 975-978.

Wurm S., Mühlhäusler P., Tryon D. (eds.). 1996. Atlas of languages of intercultural communication in the Pacific, Asia, and the Americas. [vol. 1: Maps]. Berlin, New York.

Xasanova M. 1986. Povelitel'noe naklonenie v evenkijskom jazyke. Leningrad.

Yamada Y. 2010. A preliminary study of language contacs around Uilta in Sakhalin. - Hoppō jimbun kenkȳü 3: 59-74. 